\title{
ANALISIS HUKUM KEBIJAKAN REKLAMASI TELUK BENOA DALAM KASUS PENOLAKAN OLEH MASYARAKAT PROVINSI BALI
}

\author{
M. Hanifian \\ Universitas Muhammadiyah Yogyakarta (UMY) Indonesia \\ Email: hanifianm@gmail.com
}

\begin{abstract}
Abstrak
Pada tahun 2013 Teluk Benoa ditetapkan sebagai Kawasan Perhatian Investasi (KPI) dengan rencana reklamasi Teluk Benoa Konflik kepentingan dalam kebijakan reklamasi Teluk Benoa terus terjadi. Pada satu sisi ada masyarakat yang pro reklamasi bahkan dari akademisi namun disisi lain banyak masyarakat Bali yang menolak terhadap kegiatan reklamasi. Permasalahan dalam penulisan ini bertujuan untuk menganalisis hukum mengenai kebijakan pengaturan reklamasi teluk benoa provinsi Bali, kemudian dampak dari kebijakan pembangunan reklamasi teluk benoa bali bagi lingkungan, sosial dan ekonomi masyarakat dan bentuk pengaturan hukum ideal kedepan terkait kasus penolakan reklamasi Teluk Benoa. Metode peneitian ini merupakan penelitian hukum normatif sedangkan sumber bahan hukum primer, bahan hukum sekunder maupun bahan hukum tersier. Pendekatan yang digunakan adalah pendekatan perundang-undangan dan pendekatan konsep, Teknik pengumpulan data meliputi bahan hukum primer, sekunder dan tersier yaitu data-data umum, asas-asas hukum, doktrin, dan peraturan perundang-undangan dirangkai secara sistematis sebagai susunan fakta-fakta hukum. Hasil dalam penelitian ini di dapat. Pertama, Perpres No. 51 Tahun 2014 menjadi problematika secara konstitusi, karena apabila mengacu pada Pasal 17 UU No. 1 Tahun 2014 Tentang Perubahan Atas UU No. 27 Tahun 2007 Tentang Pengelolaan Wilayah Pesisir Dan Pulau-Pulau Kecil jelas bertentangan dengan UUD 1945. Kedua, Bentuk sebenarnya dari kebijakan hukum menunjukkan bahwa hal itu berkaitan dengan keabsahan undang-undang. Regulasi Perpres, Perda, dan aturan lain tidak selalu memberikan jaminan langsung. Dalam praktek pembagian keuntungan menurut undang-undang, kebiasaan ini masih dianggap sebagai hukum kehidupan dalam masyarakat. Ketiga, ketentuan terkait kewenangan daerah dalam UU No. 1 Tahun 2014 dan Perpres No. 122 tahun 2012 masih berlaku dan belum dicabut, hal ini juga mengakibatkan ketidakpastian hukum di masyarakat.
\end{abstract}

Kata Kunci: kebijakan; reklamasi; teluk benoa

\section{Abstract}

In 2013 Benoa Bay was designated as an Investment Attention Area (KPI) with the Benoa Bayreclamation planonflik interest in benoa bay reclamation policy continues to occur. On the one hand there are people who are pro reclamation even from academics but on the other hand many Balinese people who refuse to reclamation activities. The problem in this writing aims to analyze the law on the policy of regulating the reclamation of benoa bay of Bali province, then theimpact of the development policy of the benoa bay reclamation for the environment, social

$\begin{array}{ll}\text { How to cite: } & \text { Hanifian, M. (2021) Analisis Hukum Kebijakan Reklamasi Teluk Benoa dalam Kasus Penolakan } \\ & \text { oleh Masyarakat Provinsi Bali, Syntax Idea, 3(8), https://doi.org/10.36418/syntax-idea.v3i8.1408 } \\ \text { E-ISSN: } & \text { 2684-883X } \\ \text { Published by: } & \text { Ridwan Institute }\end{array}$


and economic community and the form of ideal legal arrangements in the future related to the case of rejection of benoa bay reclamation. This method of research is normative legal research while the source of primary legal materials, secondary legal materials and legal materials tersier. The approach used isang-invitation perund approach and concept approach, Data collection techniques include primary, secondary and tertiary legal materials, namely general data, legal principles, doctrines, and laws and regulations are systematically assembled as an arrangement of legal facts. The results inthistian peneli incan be. First, Presidential Decree No. 51 of 2014 becomes a constitutional problem, because when referring to Article 17 of Law No. 1 of 2014 on Amendments to Law No. 27 of 2007 concerning the Management of Coastal Areas and Small Islands is clearly contrary to the 1945 Constitution. Second, the actual form of legal policy indicates that it has to do with the validity of the law. Regulations perpres, perda, and other rules do not always provide direct guarantees. In the practice of profit sharing according to the law, this custom is still considered the law of life in society. Third, therelevant regulations related to regional authority in Law No. 1 of 2014 and Presidential Decree No. 122 of 2012 are still valid and have not been revoked, this also causes legal uncertainty in the community.

Keywords: policy; reclamation; benoa bay

\section{Pendahuluan}

Teluk Benoa yang merupakan bagian dari kawasan konservasi dan dilindungi berubah sejak adanya Peraturan Presiden No. 32 Tahun 2011 tentang Masterplan Percepatan dan Perluasan Pembangunan Ekonomi Indonesia (MP3EI) 2011-2025. Tujuan masterplan ini adalah untuk meningkatkan pertumbuhan investasi di bidang pariwisata. Pada tahun 2013 Teluk Benoa ditetapkan sebagai Kawasan Perhatian Investasi (KPI) dengan rencana reklamasi Teluk Benoa (Wiranata, 2020).

Pada akhir masa jabatannya yaitu pada tahun 2014, Presiden Susilo Bambang Yudhoyono (SBY) menerbitkan Peraturan Presiden Nomor 51 Tahun 2014 tentang Perubahan Atas Peraturan Presiden Nomor 45 Tahun 2011 Tentang Rencana Tata Ruang Kawasan Perkotaan Denpasar, Badung, Gianyar, Dan Tabanan. Penerbitan Perpres No. 51 Tahun 2014 telah menghapus ketentuan pasal-pasal yang menegaskan bahwa status konservasi Teluk Benoa diubah menjadi kawasan pemanfaatan umum atau mengubah status Teluk Benoa menjadi kawasan budi daya yang dapat dimanfaatkan (Mahardika, 2016).

Hal tersebut secara tidak langsung akan menyebabkan kawasan konservasi diwilayah Sarbagita menjadi berkurang luasannya. Pada sisi lain, selain mendapat dukungan dari Peraturan Presiden No. 51 Tahun 2014, PT. Tirta Wahana Bali Internasional (PT. TWBI) ternyata juga mengantongi izin lokasi reklamasi nomor 445/MEN-KP/VIII/2014 dari Menteri Kelautan dan Perikanan di kawasan perairan Teluk Benoa yang meliputi Kabupaten Badung dan Kota Denpasar Provinsi Bali seluas 700 hektar. Penerbitan izin yang dilakukan dinilai terlalu cepat, secara diam-diam dan manipulatif. Mengingat salah satu syarat dari penerbitan izin lokasi maupun lingkungan harus ada pembahasan mengenai AMDAL (Analisis Mengenai Dampak Lingkungan). 
Sedangkan pelaksanaan AMDAL dari rencana reklamasi Teluk Benoa sendiri apakah sudah sesuai dengan Peraturan Pemerintah Nomor 27 Tahun 2012 tentang Izin Lingkungan, yang mengatur bahwa "Dokumen AMDAL disusun dengan melibatkan masyarakat melalui pengumuman dan konsultasi publik." (Hendri, Firdaus, \& Diana, 2016).

Kemudian, pada sisi lain Penerbitan Perpres 51 Tahun 2014 yang mengubah Teluk Benoa dari kawasan konservasi menjadi non konservasi diduga sebagai upaya pemutihan pelanggaran tata ruang, hal ini bertentangan dengan Pasal 91 Peraturan Pemerintah (PP) Nomor 15 Tahun 2010 tentang Penyelenggaraan Penataan Ruang, yang menyatakan bahwa "Revisi terhadap rencana tata ruang dilakukan bukan untuk pemutihan terhadap penyimpangan pelaksanaan pemanfaatan ruang". Penerbitan Perpres tersebut dinilai tidak melalui poreses peninjauan kembali sebagaimana diatur didalam Peraturan Pemerintah No. 15 tahun 2010 sehingga Perpres 51 Tahun 2014 semestinya harus dibatalkan oleh Presiden.

Selanjutnya pada tahun 2019, Menteri Kelautan yaitu Susi Pudjiastuti mengeluarkan aturan untuk membatalkan rencana reklamasi melalui Keputusan Menteri Kelautan dan Perikanan Nomor 46/Kepmen-Kp/2019 tentang Kawasan Konservasi Maritim Teluk Benoa di Perairan Provinsi Bali, dimana dalam aturan tersebut menyatakan bahwa "Perairan Teluk Benoa akan dikelola sebagai daerah perlindungan budaya maritim". Isu rencana reklamasi kembali mencuat setelah Edhy Prabowo menjabat jadi Menteri Kelautan dan Perikanan karena dinilai kurang tegas dalam mengambil keputusan untuk melanjutkan kebijakan dari Menteri KKP sebelumnya.

Turunan peraturan presiden tersebut memiliki efek domino, di mana Gubernur Bali menerbitkan izin lokasi untuk pelaksanaan reklamasi kepada perusahaan swasta yaitu PT. Tirta Wahana Bali Internasional melalui. Izin yang dikeluarkan oleh gubernur selanjutnya digunakan sebagai legitimasi untuk melakukan reklamasi dengan membuat daratan baru dengan luas $838 \mathrm{Ha}$.

Konflik kepentingan dalam kebijakan reklamasi Teluk Benoa terus terjadi. Pada satu sisi ada masyarakat yang pro reklamasi bahkan dari akademisi namun disisi lain banyak masyarakat Bali yang menolak terhadap kegiatan reklamasi. Hal ini karena tidak adanya manfaat atas pelaksanaan reklamasi yang dicanangkan pemerintah, karena berdampak terhadap terganggunya ekosistem lingkungan, mata pencaharian serta berpotensi hilangnya kearifan local (Tajem \& Saribulan, 2019).

Permasalahan Teluk Benoa merupakan salah satu bentuk kegagalan pembangunan yang berkelanjutan di Indonesia. Sebab rencana pembangunan tersebut ternyata tidak memenuhi kriteria studi kelayakan sebagai syarat dalam perencanaan pembangunan reklamasi (Masjhoer, 2019). Perlu diketahui bahwa model pembangunan yang baik dan bermanfaat adalah pembangunan yang tidak bersifat eksploitatif dan mengabaikan daya dukung lingkungan yang akan sangat merugikan dan mengancam penghidupan masyarakat 


\section{Metode Penelitian}

Penelitian ini merupakan penelitian hukum normatif dengan menggunakan studi kepustakaan yaitu penelitian hukum yang meletakkan hukum sebagai sebuah bangunan sistem norma (Achmad, 2013). Oleh karena itu jurnal ini menggunakan sumber bahan hukum primer, bahan hukum sekunder maupun bahan hukum tersier (Amiruddin, 2003). Penulisan jurnal ini menggunakan pendekatan perundang-undangan Statue approach (Marzuki, 2016). Dalam penelitian ini adalah adanya isu hukum mengenai ketidakpastian pengaturan perundang-undangan dibidang reklamasi khususnya reklamasi teluk benoa dan kebijakan yang tidak tepat sasaran sehingga berdampak merugikan dan menimbulkan konflik di masyarakat provinsi bali dan pendekatan Conceptual Approach atau pendekatan konseptual (Patmonodewo, 2000).Tujuannya adalah untuk membangun konsep hukum atau argumentasi hukum untuk dijadikan acuan dalam penelitian.

Teknik pengumpulan data diantaranya meliputi bahan hukum primer, sekunder dan tersier yaitu data-data umum, asas-asas hukum, doktrin, dan peraturan perundangundangan dirangkai secara sistematis sebagai susunan fakta-fakta hukum untuk mengkaji bagaimana pengaturan hukum terhadap kebijakan reklamasi teluk benoa bali serta implikasinya terhadap kesejahteraan masyarakat dan bagaimana bentuk pengaturan hukum ideal kedepan terkait kasus penolakan reklamasi Teluk Benoa.

Adapun analisis data yang digunakan dalam penelitian ini adalah deskriptif kualitatif. Analisis data kualitatif dengan menambahkan teori untuk memberi arti dan menginterpretasikan setiap bahan hukum yang telah diolah dan kemudian diuraikan secara komprehensif dan mendalam sehingga dapat ditarik sebuah kesimpulan dan hasil penelitian dapat disajikan dalam bentuk deskriptif (Mukti Fajar N.D \& Yulianto Achmad, 2013).

\section{Hasil dan Pembahasan}

\section{Analisis Pengaturan Hukum Peraturan Presiden mengenai Kebijakan Reklamasi Teluk Benoa Provinsi Bali}

Pengaturan hukum mengenai kawasan Teluk Benoa muncul adanya kebijakan strategis dari pemerintah khusus wilayah Provinsi Bali. Pada Peraturan Presiden Republik Indonesia Nomor 45 Tahun 2011 Tentang Rencana Tata Ruang Kawasan Perkotaan Denpasar, Badung, Gianyar, Dan Tabanan dalam konsiderannya menjelaskan bahwa untu melaksanakan ketentuan Pasal 21 ayat (1) Undang-Undang undang Nomor 26 Tahun 2007 tentang Penataan Ruang dan Pasal 123 ayat (4) Peraturan Pemerintah Nomor 26 Tahun 2008 tentang Rencana Tata Ruang Wilayah Nasional, perlu menetapkan Peraturan Presiden tentang Rencana Tata Ruang Kawasan Perkotaan Denpasar Badung, Gianyar, dan Tabanan.

Kemudian dari Perpres tersebut di revisi dan melahirkan Peraturan Presiden Republik Indonesia Nomor 51 Tahun 2014 Tentang Perubahan Atas Peraturan Presiden Nomor 45 Tahun 2011 Tentang Rencana Tata Ruang Kawasan Perkotaan Denpasar, Badung, Gianyar, Dan Tabanan, dalam konsideran menimbang huruf $b$ 
dijelaskan bahwa, kawasan Teluk Benoa dapat dikembangkan sebagai kawasan yang potensial guna pengembangan kegiatan ekonomi serta sosial budaya dan agama, dengan tetap mempertimbangkan kelestarian fungsi Taman Hutan Raya Ngurah Rai dan pelestarian ekosistem kawasan sekitarnya, serta keberadaan prasarana dan sarana infrastruktur di Kawasan Teluk Benoa.

Pada dasarnya kedua Peraturan Presiden tersebut telah menjelaskan mengenai tujuan diadakannya pengaturan khususnya terhadap Provinsi Bali. Tentu saja dalam penormaan Peraturan Presiden tersebut sebagai peraturan kebijakan dari Presiden untuk menentukan arah pembangunan di wilayah Provinsi Bali. Namun demikian, dalam pengaturan pembangunan tersebut, terdapat norma-norma yang menjadi rujukan peraturan yang berada di bawahnya yaitu Pasal 90 Peraturan Presiden Republik Indonesia Nomor 45 Tahun 2011 mengenai arahan peraturan zonasi untuk Zona L3 kawasan suaka alam, kawasan pelestarian alam, dan kawasan cagar budaya sebagaimana dimaksud dalam Pasal 81 ayat (2) huruf b terdiri atas:

a. Arahan peraturan zonasi untuk Taman Hutan Raya Ngurah Rai;

b. Arahan peraturan zonasi untuk Taman Wisata Alam Sangeh;

c. Arahan peraturan zonasi untuk kawasan konservasi di wilayah pesisir dan pulaupulau kecil sebagaimana dimaksud dalam Pasal 53 ayat (2) huruf c; dan

d. Arahan peraturan zonasi untuk kawasan cagar budaya dan ilmu pengetahuan sebagaimana dimaksud dalam Pasal 53 ayat (2) huruf d.

Mereklamasi kawasan konservasi artinya melanggar peraturan tersebut, terlebih banyak dampak negatif yang akan berdampak bagi kelangsungan ekosistem maupun kehidupan masyarakat. Sedangkan pihak pro beranggapan bahwa reklamasi ialah demi untuk kemajuan dan masa depan Bali, dan mereklamasi Bali ialah legal hukumnya, hal ini sesuai dengan Perpres No. 51 Tahun 2014. Inti dari Perpres ini adalah berubahnya status Teluk Benoa dari kawasan konservasi perairan menjadi kawasan pemanfaatan umum dan diijinkannya reklamasi seluas maksimal 700 hektar (Oktavia, Fauzia, Irma, \& Kusumawardani, 2014). Selain itu pihak pengembang PT TWBI juga mendapatkan izin lokasi reklamasi dari Menteri Kelautan dan Perikanan di kawasan perairan Teluk Benoa yang meliputi Kabupaten Badung Dan Kota Denpasar Povinsi Bali Seluas 700 Hektar (Wahyuni, 2019).

Mengenai sumber kewenangan pemerintah daerah mengenai reklamasi Teluk Benoa tersebut terletak pada Peraturan Presiden. Sebagaimana dalam UndangUndang No. 12 Tahun 2011 tentang Pembentukan Peraturan Perundang-Undangan Pasal 1 angka 6 menjelaskan : "Peraturan Presiden adalah Peraturan Perundang undangan yang ditetapkan oleh Presiden untuk menjalankan perintah Peraturan Perundang-undangan yang lebih tinggi atau dalam menyelenggarakan kekuasaan pemerintahan.'Kemudian mengenai keberlakuannya dijelaskan dalam Pasal 7 undang-undang tersebut, termasuk kedalam jenis dan hierarki peraturan perundangundangan.

Kata kunci dari Peraturan Presiden ini terdapat pada frasa menjalankan perintah Peraturan Perundang-undangan yang lebih tinggi atau dalam 
menyelenggarakan kekuasaan pemerintahan. Hal ini dapat dilihat dalam konsideran Perpres tersebut yaitu untuk menjalankan Pasal 4 ayat (1) Undang-Undang Dasar Negara Republik Indonesia Tahun 1945; Undang-Undang Nomor 26 Tahun 2007 tentang Penataan Ruang; Peraturan Pemerintah Nomor 26 Tahun 2008 tentang Rencana Tata Ruang Wilayah Nasional; Peraturan Presiden Nomor 45 Tahun 2011 tentang Rencana Tata Ruang Kawasan Perkotaan Denpasar, Badung, Gianyar, dan Tabanan.

Jika dikaitkan dengan materi muatannya dalam Pasal 13 adalah: "Materi muatan Peraturan Presiden berisi materi yang diperintahkan oleh Undang-Undang, materi untuk melaksanakan Peraturan Pemerintah, atau materi untuk melaksanakan penyelenggaraan kekuasaan pemerintahan." Karena muatan dalam Pasal 13 di atas berisi materi yang diperintahkan oleh Undang-Undang maka, penegasan ini bermakna, bahwa semua peraturan yang dikeluarkan oleh Presiden dalam bentukPeraturan Presiden haruslah mengacu kepada UU dan UUD, dan tidak boleh lagi bersifat mandiri seperti Keputusan Presiden di masa lalu. Walaupun demikian, bukan berarti bahwa Presiden sebagai pemegang kekuasaan eksekutif tertinggi tidak lagi bisa menerbitkan peraturan yang bersifat mandiri yang dalam kajian hukum administrasi negara dinamakan peraturan kebijakan (beleid regels/policy rules) (Husen, 2019).

Akan tetapi, Peraturan Presiden yang berfungsi untuk melaksanakan UU dan PP sama sekali tidak ada masalah, tetapi yang masih memunculkan problematika hukum adalah Perpres yang bersifat pengaturan dan mandiri mempunyai materi muatan yang tidak tertentu lingkupanya, sebab dapat saja keberadaan Perpres ini akan membuka peluang bagi Presiden untuk menyalahgunakan kekuasaan. Oleh sebab itu, perlu ada pembatasan sebagai berikut. Pertama, adanya perintah oleh peraturan yang lebih tinggi seperti yang ditentukan oleh Pasal 7 ayat (4) UU No 25 Tahun 2004 tentang Sistem Perencanaan Pembangunan Nasional harus terpenuhi. Kedua, perintah dimaksud tidak harus bersifat tegas dalam arti langsung menyebutkan bentuk hukum penuangan norma hukum yang perlu diatur, asalkan perintah pengaturan itu tetap ada. Ketiga, dalam hal perintah dimaksud memang sama sekali tidak ada, maka Perpres itu dapat dikeluarkan untuk maksud mengatur hal-hal yang (a) benar-benar bersifat teknis administrasi pemerintahan, dan (b) semata-mata dimaksudkan untuk tujuan internal penyelenggaraan ketentuan Undang-Undang dan Peraturan Pemerintah. Jika materi yang diatur benar-benar hanya berkaitan dengan soal-soalteknis administratif, barulah hal itu dapat dikatakan sebagai kewenangan atributif dari ketentuan Pasal 4 ayat (1) UUD 1945 yang menyatakan, "Presiden Republik Indonesia memegang kekuasaan pemerintahan menurut undang-undang dasar" (Usman, 2018).

Sedangkan wilayah konservasi seharusnya instrumen hukum pemerintah berupa izin lokasi Teluk Benoa tidak boleh untuk diberikan, dan secara administratif Perpres sebagai peraturan pelaksana dari UU dan PP bukan wilayah teknis, karena ayat 4 di atas sudah jelas-jelas memberikan larangan. Hal ini juga karena Perpres 
No. 51 tahun 2014 di atas berdasarkan materi muatannya merubah status Teluk Benoa dari kawasan konservasi perairan menjadi kawasan pemanfaatan umum dan diijinkannya reklamasi seluas maksimal 700 hektar.

Sebetulnya setiap peraturan perundang-undangan yang di keluarkan oleh pemerintah atau dalam hal ini adalah Presiden tidak menutup kemungkinan tidak memiliki konsekuensi hukum kepada masyarakat. Pada tataran praktis, ada juga kekhawatiran Perpres digunakan sebagai alat penyalahgunaan kekuasaan. Pandangan ini mungkin tak lepas dari sejarah 'keistimewaan' atau kemudahan yang diberikan kepada lingkaran dalam Presiden melalui Keppres pada era Orde Baru. Lagipula, tidak semua materi muatan atau norma dalam Perpres selalu benar. Itu sebabnya ada mekanisme penegakan dalam arti masyarakat yang dirugikan berhak mengajukan upaya hukum berupa hak uji materi terhadap Perpres ke Mahkamah Agung (MA). Penegakan hukum terhadap Perpres juga dimaksudkan untuk memastikan efektivitas implementasinya, dan jika ada kelemahan dapat segera ditangani (Muhammad Yasin, 2021).

Penegakan hukum tersebut di atas berupa pengujian ini karena MA memiliki kewenangan untuk melakukan pengujian peraturan perundang-undangan di bawah undang-undang. Mahkamah Agung mempunyai wewenang menguji secara materiil hanya terhadap peraturan perundang-undangan di bawah ini Undang-undang. Mahkamah Agung berwenang menyatakan tidak sah semua peraturan perundangundangan dari tingkat yang lebih rendah daripada Undang-undang atasalasan bertentangan dengan peraturan perundang-undangan yang lebih tinggi. Pencabutan peraturan perundang-undangan yang dinyatakan tidak sah tersebut, dilakukan segera oleh instansi yang bersangkutan (Angkouw, 2014). Maka dalam hal ini, yang harus dilakukan oleh Presiden ialah mencabut Perpres yang telah di putus oleh MA tersebut bertentangan dengan peraturan perundang-undangan yang berada di atasnya, sebagaimana Pasal 7 ayat (1) UU No. 12 Tahun 2011 tentang Pembentukan Peraturan Perundang-Undangan di atasnya.

Pada wilayah penegakan hukum, sebetulnya mengenai izin mengenai teluk Benoa di atas apabila mengacu pada UU No. 5 Tahun 1986 tentang Peradilan Tata Usaha Negara yang diubah dengan Pasal 1 angka 9 UU No. 51 Tahun 2009 tentang Peradilan Tata Usaha Negara, oleh Pasal 87 telah diubah dengan memberikan makna baru dengan menambah tindakan pejabat tersebut harus faktual dan tertulis yang dikeluarkan pejabat pemerintah di tiga cabang kekuasaan, yaitu eksekutif, legislatif, yudikatif. Rujukan tindakan tersebut harus berdasarkan undang-undang dan Asas Aasas Umum Pemerintahan yang Baik (AAUPB). Kemudian sifatnya harus final dalam arti luas yang berakibat hukum. Apabila keputusan ternyata merugikan, dapat dilakukan permohonan di Pengadilan Tata Usaha Negara terhadap K.TUN tersebut. Kemudian, tindakan malaadiministrasi penyelenggara pelayanan publik dapat dilaporkan kepada Ombudsman (Arliman, 2016).

Karena itu, ada beberapa parameter bagi masyarakat Bali melihat fenomena ini, dengan mengacu pada: (i) pembuatan hukum ( 'the legislation of law' atau 'law 
and rule making'), (ii) sosialisasi, penyebarluasan dan bahkan pembudayaan hukum (socialization and promulgation of law, dan (iii) penegakan hukum (the enforcement of law). Ketiganya membutuhkan dukungan (iv) adminstrasi hukum (the administration of law) yang efektif dan efisien yang dijalankan oleh pemerintahan (eksekutif) yang bertanggungjawab (accountable) (Jimly Asshiddiqie, 2021).

Mengacu pada Keputusan Mahkamah Konstitusi pda tanggal 9 Juni 2010 atas perkara No. 3/PUU/VIII/2010 yang isinya secara singkat menentukan bahwa pemberian HP-3 oleh Pemerinah, megancam keberadaan hak-hak masyarakat tradisional kearifan masyarakat lokal atas wayah pesisir dan pulau-ulau kecil. Kebebasan berdasar kerakayatan dan kemanusiaan yang membuka adanya kesepakatan-kesepakatan antara masyaraat tradisional dengan pengusaha antara masyarakat tradisional dengan penusaha di uar mereka. Sekalipun disebutkan adanya musywarah (atau kesepakatan), namun semata-mata untuk pembayaran ganti rugi. Pemerinah sebagai penguaha, berdasar otoritasnya secara seha mengambil atau mengosongkan hak msyrakat tradisional atas wilayah pesisir dan pulau-pulau kecil (Titahelu, 2016).

Pada isi materi UU No. 1 tahun 2014 Tentang Perubahan Atas UndangUndang Nomor 27 Tahun 2007 Tentang Pengelolaan Wilayah Pesisir Dan PulauPulau Kecil Pasal 60 ayat (1) disebutkan bahwa dalam Pengelolaan Wilayah Pesisir dan Pulau-Pulau Kecil, Masyarakat mempunyai hak untuk:

1. Memperoleh akses terhadap bagian Perairan Pesisir yang sudah diberi Izin Lokasi dan Izin Pengelolaan;

2. Mengusulkan wilayah penangkapan ikan secara tradisional ke dalam RZWP-3$\mathrm{K}$;

3. Mengusulkan wilayah Masyarakat Hukum Adat ke dalam RZWP-3-K;

4. Melakukan kegiatan pengelolaan Sumber Daya Pesisir dan Pulau-Pulau Kecil berdasarkan hukum adat yang berlaku dan tidak bertentangan dengan ketentuan peraturan perundangundangan;

5. Memperoleh manfaat atas pelaksanaan Pengelolaan Wilayah Pesisir dan PulauPulau Kecil;

6. Memperoleh informasi berkenaan dengan Pengelolaan Wilayah Pesisir dan Pulau-Pulau Kecil;

7. Mengajukan laporan dan pengaduan kepada pihak yang berwenang atas kerugian yang menimpa dirinya yang berkaitan dengan pelaksanaan Pengelolaan Wilayah Pesisir dan Pulau-Pulau Kecil;

8. Menyatakan keberatan terhadap rencana pengelolaan yang sudah diumumkan dalam jangka waktu tertentu;

9. Melaporkan kepada penegak hukum akibat dugaan pencemaran, pencemaran, dan/atau perusakan Wilayah Pesisir dan Pulau-Pulau Kecil yang merugikan kehidupannya;

10. Mengajukan gugatan kepada pengadilan terhadap berbagai masalah Wilayah Pesisir dan Pulau-Pulau Kecil yang merugikan kehidupannya. 


\section{Memperoleh ganti rugi; dan}

12. Mendapat pendampingan dan bantuan hukum terhadap permasalahan yang dihadapi dalam Pengelolaan Wilayah Pesisir dan Pulau-Pulau Kecil sesuai dengan ketentuan peraturan perundang-undangan.

Apabila melihat kembali UU No. 6 Tahun 1974 Tentang KetentuanKetentuan Pokok Kesejahteraan Sosial Pasal 2 ayat 1 berbunyi: "Kesejahteraan Sosial" ialah suatu tata kehidupan dan penghidupan sosial materiil maupun spiritual yang diliputi oleh rasa keselamatan, kesusilaan, dan ketenteraman lahir bathin, yang memungkinkan bagi setiap Warganegara untuk mengadakan usaha pemenuhan kebutuhan-kebutuhan jasmaniah, rohaniah dan sosial yang sebaik-baiknya bagi diri, keluarga serta masyarakat dengan menjunjung tinggi hak-hak asasi serta kewajiban manusia sesuai dengan Pancasila.

Meskipun kebijakan Politik Hukum sebagaimana dikemukakan itu dalam realitas telah memperlihatkan kaitannya dengan keefektifan hukum, peraturan undang-undangan tidak selalu memberikan jaminan langsung. Dalam praktik bagi hasil sebagaimana diatur oleh UU juga masih mempertimbangkan adat kebiasaan sebagai the living law dalam masyarakat (Djauhari, 2007).

Selain itu terdapat 70 titik suci di kawasan Teluk Benoa ini yang membedakan kawasan konservasi maritim Teluk Benoa dengan kawasan maritim di kawasan perairan lainnya Puluhan titik suci itu terdiri dari 31 pura yang terletak di darat dan pesisir teluk, serta kawasan hutan bakau. Kemudian, ada 19 daratan pasang surut - disebut muntik oleh masyarakat lokal yang pada saat Teluk Benoa pasang, daratan itu tenggelam. Ada lagi sawangan atau alur teluk yang juga disucikan oleh masyarakat dan punya nama-nama tradisional (Ayomi Amindoni, 2021).

Rencana proyek reklamasi Teluk Benoa mendapat penolakan dari masyarakat Bali karena menurut mereka reklamasi berdampak negatif pada lingkungan, sosial dan adat budaya masyarakat Bali. Hal ini terjadi karena masyarakat Bali yang belum memahami keuntungan atau dampak positif dari proyek reklamasi bagi masyarakat Bali terutama masyarakat di wilayah Kabupaten Badung. Pengelolaan Wilayah Pesisir dan Pulau-Pulau Kecil harus dilakukan dengan tetap mengakui dan menghormati kesatuan-kesatuan Masyarakat hukum adat serta hak-hak tradisionalnya sesuai dengan prinsip Negara Kesatuan Republik Indonesia, serta mengakui dan menghormati masyarakat lokal dan masyarakat tradisional yang bermukim di wilayah pesisir dan pulau-pulau kecil. Akan tetapi kebijakan terkait mereklamasi Teluk Benoa tanpa melibatkan masyarakat hukum adat di Bali (Dewi, 2019).

Menurut John Rawls, kebebasan berkeyakinan dibatasi oleh kepentingan umum dalam keteraturan dan perlindungan masyarakat. Pembatasan itu sendiri segera bisa diambil dari sudut pandang kontrak. Pertama, penerimaan terhadap pembatasan ini tidak membuktikan bahwa kepentingan publik adalah lebih unggul dibanding kepentingan religius dan moral, tidak pula pemerintah memandang 
persoalan-persoalan religius merupakan perkara-perkara yang biasa saja atau mengklaim hak untuk menindas keyakinan-keyakinan filosofis ketika semua itu dipandag berbenturan dengan urusan negara (Rawls, 2006).

Menurut Antony Allot kita dapat mengatakan bahwa hukum itu efektif, bila tujuannya preventif (pencegahan), eksistensinya dan penerapannya mencegah sikap yang tidak disetujui. Bila tujuannya kuratif, untuk memperbaiki suatu kekurangan atau kerusakan, keberhasilannya diukur sejauh mana kekurangan atau kerusakan hilang. Hukum yang efektif umurnnya harus dilakukan sesuai dengan tujuannya; bila terjadi kegagalan, harus ada kemungkinan dan cara perbaikan yang mudah. Bila diharuskan untuk menerapkan hukurn di dalam keadaan yang berbeda atau baru, hukum harus cukup dapat disesuaikan (Djauhari, 2007).

Timbulnya suatu sengketa dalam masyarakat, memberi tanda bahwa masyarakat memerlukan tindakan penyelesaian. Pembiaran terhadap sengketa tersebut tanpa penyelesaian aan menghabat terciptanya suatu kerja sama yang produktif dalam masyarakat. Pada saat tersebut dibutuhkan mekanisme yang mampu mengintegrasikan kekuatan-kekuatan dan kepentingan-kepentingan yang menimbulkan konflik dalam masyarakat, sehingga dapat diciptakan atau dipulihkan proses kerja sama yang produktif (Rahardjo, 2009).Hal ini juga di rasa penting untuk dapat melihat konflik antara masayrakat Bali dengan Pemerintah Daerah Telok Benoa.

Pengembangan pariwisata Bali saat ini terlalu dibebani dengan sarana dan prasarana modern yang justru mengenyampingkan orisinalitas kebudayaan Bali. Eksploitasi alam dan budaya Bali demi kepentingan ekonomi melupakan hakekat bahwa kebudayaan Bali bersumber dari Tri Hita Karana yang salah satunya menyebutkan hubungan yang harmonis dengan alam. Sudah seharusnya masyarakat Bali berjuang menjaga kelestarian alamnya. Teluk Benoa tidak hanya memiliki arti ekologis namun juga religius bagi masyarakat Hindu di Bali. Menjadikan Teluk Benoa sebagai sentra bisnis masa depan melalui reklamasi Teluk Benoa ditentang oleh masyarakat Bali pada umumnya. Hilangnya fungsi ekologis dan religius Teluk Benoa akan berakibat pada tergerusnya identitas masyarakat Bali karena mereka percaya bahwa identitas dibangun melalui keseimbangan hubungan yang harmonis manusia dengan alam, sesama manusia dan pencipta-Nya (Ni Wayan Rainy Priadarsini S., Putu Ratih Kumala Dewi, 2018). 


\section{Kesimpulan}

Pada penelitian yang telah dilakukan, ada beberapa point yang bisa diambil, Pertama Perubahan Perpres No. 51 Tahun 2014 juga ikut berubahnya status Teluk Benoa dari kawasan konservasi perairan menjadi kawasan pemanfaatan umum dan diijinkannya reklamasi seluas maksimal 700 hektar. Kedua, keputusan Mahkamah Konstitusi pada tanggal 9 Juni 2010 atas perkara No. 3/PUU/VIII/2010 yang isinya secara singkat menentukan bahwa pemberian HP-3 oleh Pemerinah, megancam keberadaan hak-hak masyarakat tradisional kearifan masyarakat lokal atas wayah pesisir dan pulau-ulau kecil. Ketiga, Upaya penyusunan regulasi tentang reklamasi dengan mengintegrasikan berbagai rencana departemen, mengatasi tumpang tindih pengelolaan, pemanfaatan dan konflik kewenangan, serta memberikan kepastian hukum, oleh karena itu perlu dibangun kembali pengaturan reklamasi. 


\section{BIBLIOGRAFI}

Achmad, Mukti Fajar N. dan Yulianto. (2013). Dualisme Penelitian Hukum Normatif \& Empiris. Yogyakarta: Penerbit Pustaka Pelajar.Google Scholar

Amiruddin, dan H. Zainal Asikin. (2003). Pengantar Metode Penelitian Hukum. Jakarta: PT Raja Grafindo Persada.

Angkouw, Kevin. (2014). Fungsi Mahkamah Agung Sebagai Pengawas Internal Tugas Hakim Dalam Proses Peradilan. Lex Administratum, 2(2). Google Scholar

Arliman, Laurensius. (2016). Penguatan Perlindungan Anak Dari Tindakan Human Trafficking Di Daerah Perbatasan Indonesia. Jurnal Selat, 4(1), 15-32. Google Scholar

Ayomi Amindoni. (2021). Teluk Benoa jadi kawasan konservasi maritim, 'tidak sertamerta membatalkan proyek reklamasi. Ayomi Amindoni.

Dewi, Gangga Santi. (2019). Penolakan masyarakat terhadap reklamasi teluk benoa provinsi bali. Diponegoro Private Law Review, 4(1). Google Scholar

Djauhari, Djauhari. (2007). Politik Hukum Negara Kesejahteraan Indonesia (Studi Tentang Kebijakan Regulasi dan Institusionalisasi Gagasan Kesejahteraan Sosial Ekonomi Masyarakat Nelayan di Jawa Tengah). Jurnal Hukum IUS QUIA IUSTUM, 14(4). Google Scholar

Hendri, Mutia Fadhillah, Firdaus, Emilda, \& Diana, Ledy. (2016). Implementasi Peraturan Pemerintah Nomor 27 Tahun 2012 Tentang Izin Lingkungan sebagai Instrumen dalam Mewujudkan Pembangunan Berkelanjutan di Kabupaten Kampar. Riau University. Google Scholar

Husen, Ahmad. (2019). Eksistensi Peraturan Presiden Dalam Sistem Peraturan Perundang-Undangan. Lex Scientia Law Review, 3(1), 69-78. Google Scholar

Jimly Asshiddiqie. (2021). Penegakan Hukum. http://www.jimly.com/makalah/namafile /56/Penegakan_Hukum.pdf.

Mahardika, Reza Putra. (2016). Rencana Reklamasi Teluk Benoa Peraturan Presiden Nomor 51 Tahun 2014 Tentang Perubahan Atas Peraturan Presiden Nomor 45 Tahun 2011 Tentang Rencana Tata Ruang Kawasan Perkotaan Denpasar, Badung, Gianyar, Dan Tabanan. Kumpulan Jurnal Mahasiswa Fakultas Hukum. Google Scholar

Marzuki, Peter Mahmud. (2016). Penelitian Hukum (Cetakan 11). Jakarta: PT. Khrisma Putra Utama.

Masjhoer, Jussac Maulana. (2019). Pengantar Wisata Bahari. Jussac M Masjhoer. Google Scholar 
Muhammad Yasin. (2021). Mengenal Lebih Jauh Jenis Peraturan Bernama Perpres. https://pro.hukumonline.com/berita/baca/lt5e255e98a68ae/mengenal-lebih-jauhjenis-peraturan-bernama-perpres

Ni Wayan Rainy Priadarsini S., Putu Ratih Kumala Dewi, A. A. A. Intan Parameswari. (2018). Gerakan Tolak Proyek Reklamasi Teluk Benoa sebagai Penguatan Identitas Kultural Masyarakat Bali. Jurnal Kajian Bali, 08(2), 174.

Oktavia, Alfania Riski, Fauzia, F., Irma, C., \& Kusumawardani, Nungky. (2014). Analisis Peraturan Presiden No. 51 tahun 2014 mengenai Reklamasi Teluk Benoa. Makalah Politik Kebijakan Publik. Depok. FISIP Universitas Indonesia. Google Scholar

Patmonodewo, Soemiarti. (2000). Pendidikan anak prasekolah. Rineka Cipta bekerjasama dengan Departemen Pendidikan \& Kebudayaan. Google Scholar

Rahardjo, Satjipto. (2009). Membangun dan merombak hukum Indonesia: sebuah pendekatan lintas disiplin. Genta Pub. Google Scholar

Rawls, John. (2006). A Theory of Justice, Terjemah, Uzair Fauzan dan Heru Prasetyo, Teori Keadilan: Dasar-Dasar Filsafat Politik untuk Mewujudkan Kesejahteraan Sosial dalam Negara hlm. 72-74 (Cetakan I). Yogyakarta: Pustaka Pelajar.

Subekti, Slamet. (n.d.). Kawasan Konservasi Maritim dan SDG 14: Prospek Teluk Benoa Bali. Endogami: Jurnal Ilmiah Kajian Antropologi, 4(1), 73-82. Google Scholar

Tajem, Made Dwi Astika, \& Saribulan, Nur. (2019). Konflik Kepentingan Dalam Kebijakan Reklamasi Kawasan Teluk Benoa Provinsi Bali Kajian tentang Konsep Tri Hita Karana. Jurnal Kebijakan Pemerintahan, 37-55. Google Scholar

Titahelu, Ronald Z. (2016). Penetapan Asas-Asas Hukum Umum dalam Penggunaan Tanah untuk Sebesar-besar Kemakmuran Rakyat (Suatu Kajian Filsafati dan Teoretik tentang Pengaturan dan Penggunaan Tanah di Indonesia). Deepublish. Google Scholar

Usman, U. (2018). Hukuman Penjara Bagi Anak Menurut Ulama Nu Lampung Dalam Perspektif Hukum Islam. Uin Raden Intan Lampung. Google Scholar

Wahyuni, Eka Sri. (2019). Resistensi Komunitas For Bali Terhadap Reklamasi Teluk Benoa Oleh Pt. Tirta Wahana Bali Internasional. Universitas Airlangga. Google Scholar

Wiranata, I. Made Anom. (2020). Gerakan Warga Desa Adat Di Bali Menentang Reklamasi Teluk Benoa: Studi Fenomenologi Hermeneutik Dalam Perspektif Gerakan Sosial Baru. Universitas Airlangga. Google Scholar 
M. Hanifian

Copyright holder:

M. Hanifian (2021)

\section{First publication right:}

Syntax Idea

This article is licensed under:

(c) (†) (?) 